\title{
Short communication: Effect of heat stress during the dry period on gene expression in mammary tissue and peripheral blood mononuclear cells
}

\author{
S. Tao, ${ }^{*}$ E. E. Connor, † J. W. Bubolz, ${ }^{*}$ I. M. Thompson, ${ }^{*}$ B. C. do Amaral, ${ }^{* 1}$ M. J. Hayen, ${ }^{*}$ and G. E. Dahl*2 \\ ${ }^{*}$ Department of Animal Sciences, University of Florida, Gainesville 32611 \\ †Bovine Functional Genomics Laboratory, USDA-ARS, Beltsville Agricultural Research Center, Beltsville, MD 20705
}

\begin{abstract}
Heat stress (HT) during the dry period compromises mammary gland development, decreases future milk production, and impairs the immune status of dairy cows. Our objective was to evaluate the effect of cooling HT cows during the dry period on gene expression of the mammary gland and peripheral blood mononuclear cells (PBMC). Cows were dried off $46 \mathrm{~d}$ before their expected calving and assigned to 2 treatments, HT or cooling (CL). Cows in the CL group were cooled with sprinklers and fans whereas HT cows were not. After parturition, all cows were housed in a freestall barn with cooling. The PBMC were isolated at dry-off and at $-20,2$, and $20 \mathrm{~d}$ relative to calving from a subset of cows (HT, $\mathrm{n}=9$; CL, $\mathrm{n}=10$ ), and mammary biopsies were taken at the same intervals $(\mathrm{HT}, \mathrm{n}=7 ; \mathrm{CL}, \mathrm{n}=$ 6) for RNA extraction. Gene expression was assessed using a custom multiplex gene expression assay based on traditional reverse transcription-PCR. Genes involved in prolactin (PRL) signaling [PRL receptor long form, PRL receptor short form, suppressor of cytokine signaling $(S O C S)^{2}$, SOCS3, IGF2, IGF binding protein 5 , and cyclin D1], fatty acid metabolism (acetyl-CoA carboxylase $\alpha(A C A C A)$ and lipoprotein lipase $(L P L)$ ], and $I G F 1$ were evaluated in mammary tissue, and genes related to fatty acid metabolism [ACACA, fatty acid synthase $(F A S N)$, and $L P L]$, cytokine production $[I L 6, I L 8$, and tumor necrosis factor $(T N F)]$, and $I G F 1$ were evaluated in PBMC. No differences were observed in PRL signaling or fatty acid metabolism gene expression in the mammary gland. In PBMC, HT cows had greater mRNA expression of IGF1 and TNF during the transition period relative to CL and upregulated IL8 and downregulated FASN mRNA expression at $2 \mathrm{~d}$ relative to calving. We conclude that cooling HT cows during the dry period alters expression of genes
\end{abstract}

\footnotetext{
Received June 5, 2012.

Accepted October 4, 2012.

${ }^{1}$ Current address: Land O'Lakes Purina Feeds LLC, PO Box 64101 MS 2040, St. Paul, MN.

${ }^{2}$ Corresponding author: gdahl@ufl.edu
}

involved in cytokine production and lipid metabolism in PBMC.

Key words: dry period, heat stress, peripheral blood mononuclear cells, mammary gland

\section{Short Communication}

Environmental modification during the dry period such as heat stress (HT) and photoperiod exert dramatic effects on dairy cows. For example, compared with long-day photoperiod (16 h light: $8 \mathrm{~h}$ dark, LDPP), short-day photoperiod ( $8 \mathrm{~h}$ light: $16 \mathrm{~h}$ dark, SDPP) upregulates mammary gland remodeling before parturition (Wall et al., 2005) and increases milk yield of cows in the next lactation (Auchtung et al., 2005). Similar to SDPP, cooling also enhances mammary growth during the dry period and improves lactation performance after parturition (Tao et al., 2011). Prolactin (PRL) plays important roles in bovine lactogenesis and mammogenesis (Tucker, 2000), and evidence indicates that the altered PRL signaling mediates photoperiodic effects on mammary gland development during the dry period. Specifically, SDPP decreases the concentration of PRL in blood but increases gene expression of PRL receptor $(\boldsymbol{P R} \boldsymbol{L} \boldsymbol{R})$ in mammary tissue relative to LDPP (Auchtung et al., 2005). The cellular mechanism of the compromised mammary gland development by HT during the dry period is still unknown and is thought to be associated with modified PRL signaling (Tao et al., 2011). However, data related to gene expression in the PRL signaling of mammary gland in HT or cooled (CL) dry cows are still not available. In addition, the effect of cooling HT dry cows on gene expression involved in FA metabolism in the mammary gland has yet to be evaluated.

Heat stress also influences the animal's immune function during the dry period. Relative to CL cows, HT animals when dry have decreased proliferation of peripheral blood mononuclear cells (PBMC) and decreased production of tumor necrosis factor (TNF)- $\alpha$ in response to mitogen in vitro during the transition period (do Amaral et al., 2010). However, the effect of dry period HT on endogenous inflammatory cytokine gene expression of PBMC during the transition period 
has never been evaluated. In addition, gene expression data for IGF1 and enzymes involved in the FA metabolism of PBMC in HT dry cows are not available. We hypothesized that HT during the dry period suppresses PRL signaling and FA metabolism in the mammary gland and alters inflammatory cytokine gene expression of PBMC. Therefore, our objective was to evaluate the effect of HT and CL during the dry period on gene expression of the mammary gland and PBMC of dairy cows during the transition period.

Cows used in the current study were from a subset of animals in a larger study, and details of treatment and management of animals were reported previously (Tao et al., 2011). University of Florida Institute of Food and Agricultural Sciences Animal Research Committee approved all procedures. Briefly, cows were dried off approximately $46 \mathrm{~d}$ before expected calving date and randomly assigned to 2 treatments, HT or CL. During the dry period, CL cows were cooled with shade, sprinklers, and fans, and HT cows were provided with shade only. After parturition, all cows were managed as a single group. Mammary biopsies were collected from a subset of animals ( $\mathrm{HT}, \mathrm{n}=7$; $\mathrm{CL}, \mathrm{n}=6$ ) at dry-off and at $-20,2$, and $20 \mathrm{~d}$ relative to calving, and PBMC were isolated at the same intervals $(\mathrm{HT}, \mathrm{n}=9$; CL, n $=10$ ). The mammary biopsy procedure was described previously (Tao et al., 2011), and PBMC isolation was performed based on methods reported by do Amaral et al. (2010).

The RNeasy Midi kit (Qiagen, Valencia, CA) was used for total RNA extraction of the mammary tissues and PBMC, following the manufacturer's protocol with on-column DNase treatment. Quality of RNA was assessed using the Agilent 2100 Bioanalyzer with RNA 6000 Nano LabChip kits (Agilent Technologies, Palo Alto, CA) and RNA concentration was determined using the ND-1000 spectrophotometer (NanoDrop Technologies, Wilmington, DE). Gene expression was evaluated by a custom 22-gene multiplex expression assay on the GeXP Genetic Analysis System and GeXP Start Kit (Beckman Coulter Inc., Brea, CA), which is based on traditional reverse transcription-PCR. Assay optimization, generation of standard curves, and assay procedures were performed based on manufacturer's instructions. Details can be found in Connor et al. (2010). Briefly, total RNA (100 ng) was reverse transcribed with pooled gene-specific reverse primers containing a universal sequence attached at the $5^{\prime}$ end (Table 1). The KanR RNA (2.5 pg/reaction) provided in the GeXP Start Kit was added as an internal normalization control. Negative control reactions in the absence of reverse transcriptase were also performed on each sample to confirm the absence of contaminating genomic DNA. Reaction conditions were $48^{\circ} \mathrm{C}$ for
$1 \mathrm{~min}, 42^{\circ} \mathrm{C}$ for $60 \mathrm{~min}, 95^{\circ} \mathrm{C}$ for $5 \mathrm{~min}$, and then holding at $4^{\circ} \mathrm{C}$. Reactions for subsequent PCR included 25 $\mathrm{mM} \mathrm{MgCl} 2$, pooled forward primers, cDNA, PCR buffer, and Thermo-Start Taq DNA polymerase (Thermo Scientific, Waltham, MA), according to the manufacturer's instructions and optimized conditions. The PCR reaction conditions were $95^{\circ} \mathrm{C}$ for $10 \mathrm{~min}, 94^{\circ} \mathrm{C}$ for 30 $\mathrm{s}, 55^{\circ} \mathrm{C}$ for $30 \mathrm{~s}$, and $70^{\circ} \mathrm{C}$ for $1 \mathrm{~min}$ for 35 cycles. The PCR products were diluted in sample loading solution provided in the GeXP Start Kit plus DNA size standard 400 and analyzed by GenomeLab GeXP Genetic Analysis System (Beckman Coulter Inc.). Data were exported to the eXpress Profiler Program (Beckman Coulter Inc.), calculated as area under the curve, and normalized to KanR RNA. The final data were normalized to the most stably expressed reference genes as determined by the GeNorm program (http://medgen. ugent.be/ jvdesomp/genorm/) using the GeneQuant Tool (Beckman Coulter Inc.) and reported as the value relative to the geometric mean expression of the reference genes. For PBMC RNA, gene expression was normalized to that of $\beta-2$ microglobulin and $G A P D H$ (GeNorm M-value $=0.33$ ) and for mammary RNA, expression was normalized to that of ATP synthase, $\beta-2$ microglobulin, and hypoxanthine phosphoribosyltransferase 1 (M-value <0.70).

Gene expression data were analyzed using repeated measures of PROC MIXED of SAS 9.2 (SAS Institute, Cary, NC), and least squares means \pm standard errors of the means are presented. The statistical model included treatment, time, and treatment $\times$ time interaction, with cow within treatment as a random effect. The data from the samples taken at dry-off were considered as covariates and included in the SAS model. If a treatment $\times$ time effect was observed, the treatment effect at individual time points was obtained by the SLICE function in SAS models. Data were considered significant if $P<0.05$ or a trend if $P<0.15$.

Tao et al. (2011) reported the details of the physiological responses of the cows within the experiment. Briefly, during the dry period, the temperature-humidity index ranged from 72 to 81 throughout a day and averaged 76.6 for all cows. Compared with CL cows, HT cows had elevated body temperatures during the dry period, averaging 38.98 and $39.34^{\circ} \mathrm{C}$, respectively. Relative to CL cows, HT cows had a reduced mammary cell proliferation rate at $-20 \mathrm{~d}$ relative to calving but not at other time points. We observed no differences between treatments for the mammary cell apoptotic rate at any time point in the transition period. Compared with cooling, heat stress during the dry period also increased the PRL concentration in plasma .

In mammary tissue, no treatment or treatment $x$ time effects were observed in mRNA expression for 
Table 1. Genes evaluated using a multiplex gene expression assay, their primer sequences and amplicon sizes, GenBank accession numbers used in primer design, and standard curve fit $\left(R^{2}\right)$

\begin{tabular}{|c|c|c|c|c|c|c|}
\hline $\begin{array}{l}\text { Gene } \\
\text { symbol }\end{array}$ & Gene name & $\begin{array}{l}\text { Amplicon } \\
\text { size (bp) }\end{array}$ & Primer $^{1}$ & Sequence $\left(5^{\prime}\right.$ to $\left.3^{\prime}\right)$ with universal sequence & $\begin{array}{l}\text { GenBank } \\
\text { accession no. }\end{array}$ & $\mathrm{R}^{2}$ \\
\hline$A C A C A$ & Acetyl-CoA carboxylase $\alpha$ & 200 & $\begin{array}{l}\mathrm{F} \\
\mathrm{R}\end{array}$ & $\begin{array}{l}\text { AGGTGACACTATAGAATATCTCCTCCAACCTCAACCAC } \\
\text { GTACGACTCACTATAGGGAAAGCAGCCCATCACTTCATC }\end{array}$ & NM_174224 & $>0.993$ \\
\hline$A T P 5 B$ & ATP synthase & 221 & $\mathrm{~F}$ & AGGTGACACTATAGAATACCCTCAAGGAGACCATCAAA & NM_175796 & $\geq 0.998$ \\
\hline B2M & Beta-2 microglobulin & 193 & $\begin{array}{l}\mathrm{F} \\
\mathrm{R}\end{array}$ & $\begin{array}{l}\text { AGGTGACACTATAGAATAAGCGTCCTCCAAAGATTCAA } \\
\text { GTACGACTCACTATAGGGAACAGGTCTGACTGCTCCGAT }\end{array}$ & NM_173893 & $>0.999$ \\
\hline$C C N D 1$ & Cyclin D1 & 300 & $\begin{array}{l}\mathrm{F} \\
\mathrm{R}\end{array}$ & $\begin{array}{l}\text { AGGTGACACTATAGAATACATGAACTACCTGGACCGCT } \\
\text { GTACGACTCACTATAGGGAGCATCTTGGAGAGGAAGTGC }\end{array}$ & NM_001046273 & $>0.998$ \\
\hline$F A S N$ & Fatty acid synthase & 340 & $\begin{array}{l}\mathrm{F} \\
\mathrm{R}\end{array}$ & $\begin{array}{l}\text { AGGTGACACTATAGAATAGTCTTCTCCTCCGTGAGCTG } \\
\text { GTACGACTCACTATAGGGAACGGGATGTAGCCTTCTCTG }\end{array}$ & NM_001012669 & $>0.997$ \\
\hline$G A P D H$ & $\begin{array}{l}\text { Glyceraldehyde-3-phosphate } \\
\text { dehydrogenase }\end{array}$ & 172 & $\mathrm{~F}$ & AGGTGACACTATAGAATAGATTGTCAGCAATGCCTCCT & NM_001034034 & $>9.997$ \\
\hline HPRT1 & $\begin{array}{l}\text { Hypoxanthine } \\
\text { phosphoribosyltransferase } 1\end{array}$ & 242 & $\begin{array}{l}\mathrm{R} \\
\mathrm{F}\end{array}$ & $\begin{array}{l}\text { GTACGACTCACTATAGGGACCATCCACAGTCTTCTGGGT } \\
\text { AGGTGACACTATAGAATAGCCGACCTGTTGGATTACAT }\end{array}$ & NM_001034035 & $>0.999$ \\
\hline$I G F B P 5$ & $\begin{array}{l}\text { Insulin-like growth factor } \\
\text { binding protein } 5\end{array}$ & 142 & $\begin{array}{l}\mathrm{R} \\
\mathrm{F}\end{array}$ & $\begin{array}{l}\text { GTACGACTCACTATAGGGAGCATTGTCTTCCCAGTGTCA } \\
\text { AGGTGACACTATAGAATAGGTTTGCCTGAACGAAAAGA }\end{array}$ & NM_001105327 & $>0.999$ \\
\hline$I G F 1$ & Insulin-like growth factor 1 & 179 & $\begin{array}{l}\mathrm{R} \\
\mathrm{F} \\
\mathrm{R}\end{array}$ & $\begin{array}{l}\text { GTACGACTCACTATAGGGAGAGTAGGTCTCCTCTGCCATCT } \\
\text { AGGTGACACTATAGAATAGTTGGTGGATGCTCTCCAGT } \\
\text { GTACGACTCACTATAGGGACCTCCTCAGATCACAGCTCC }\end{array}$ & NM_001077828 & $\geq 0.999$ \\
\hline IGF2 & Insulin-like growth factor 2 & 214 & $\begin{array}{l}\mathrm{F} \\
\mathrm{R}\end{array}$ & $\begin{array}{l}\text { AGGTGACACTATAGAATAATCAATTTGCTCCCTACCCC } \\
\text { GTACGACTCACTATAGGGAAGGCTCCACTCTCCACTCAA }\end{array}$ & NM_174087 & $>0.999$ \\
\hline IL6 & Interleukin 6 & 358 & $\begin{array}{l}\mathrm{F} \\
\mathrm{R}\end{array}$ & $\begin{array}{l}\text { AGGTGACACTATAGAATATGCTTGATCAGAACCACTGC } \\
\text { GTACGACTCACTATAGGGACTACCACAATCATGGGAGCC }\end{array}$ & NM_173923 & $\geq 0.995$ \\
\hline IL 8 & Interleukin 8 & 307 & $\begin{array}{l}\mathrm{F} \\
\mathrm{R}\end{array}$ & $\begin{array}{l}\text { AGGTGACACTATAGAATATGAATTTGGAGAAATGGGAAA } \\
\text { GTACGACTCACTATAGGGAGGCCAGGCATCTCAAAAGTA }\end{array}$ & NM_173925 & $>0.999$ \\
\hline$L P L$ & Lipoprotein lipase & 365 & $\begin{array}{l}\mathrm{F} \\
\mathrm{R}\end{array}$ & $\begin{array}{l}\text { AGGTGACACTATAGAATACGGAGGTGGATATTGGAGAA } \\
\text { GTACGACTCACTATAGGGAAAGCACTGGGCATCTTTTGT }\end{array}$ & NM_001075120 & $>0.995$ \\
\hline$P R L R-L$ & Prolactin receptor, long form & 379 & $\begin{array}{l}\mathrm{F} \\
\mathrm{R}\end{array}$ & $\begin{array}{l}\text { AGGTGACACTATAGAATAAGCAACTGATTGGGAGACTCA } \\
\text { GTACGACTCACTATAGGGATCGGACTTGCCCTTCTCC }\end{array}$ & NM_001039726 & $>0.999$ \\
\hline$P R L R-S$ & Prolactin receptor, short form & 386 & $\begin{array}{l}\mathrm{F} \\
\mathrm{R}\end{array}$ & $\begin{array}{l}\text { AGGTGACACTATAGAATAAGCAACTGATTGGGAGACTCA } \\
\text { GTACGACTCACTATAGGGAAAGGCGAGAAGGCTGTGATA }\end{array}$ & NM_174155 & $\geq 0.995$ \\
\hline SOCS2 & $\begin{array}{l}\text { Suppressor of cytokine } \\
\text { signaling } 2\end{array}$ & 260 & $\mathrm{~F}$ & AGGTGACACTATAGAATAGAGGCACCAGAAGGAACTTT & NM_177523 & $\geq 0.994$ \\
\hline SOCS3 & $\begin{array}{l}\text { Suppressor of cytokine } \\
\text { signaling } 3\end{array}$ & 158 & $\begin{array}{l}\mathrm{R} \\
\mathrm{F}\end{array}$ & $\begin{array}{l}\text { GTACGACTCACTATAGGGATCCGCTTATCCTTGCACATC } \\
\text { AGGTGACACTATAGAATAGGCCACTCTCCAACATCTCT }\end{array}$ & NM_174466 & $>0.994$ \\
\hline$T N F$ & Tumor necrosis factor & 207 & $\begin{array}{l}\mathrm{R} \\
\mathrm{F} \\
\mathrm{R}\end{array}$ & $\begin{array}{l}\text { GTACGACTCACTATAGGGACTAAAGCGGGGCATCGTACT } \\
\text { AGGTGACACTATAGAATAAACTCTCCCTTCCTGCCAAT } \\
\text { GTACGACTCACTATAGGGAAGGACACCTTGACCTCCTGA }\end{array}$ & NM_173966 & $>0.999$ \\
\hline
\end{tabular}

${ }^{1} \mathrm{~F}=$ forward; $\mathrm{R}=$ reverse. 
most of the genes examined (Table 2), except for a slight trend to increase $(P=0.15)$ gene expression of IGF binding protein 5 (IGFBP5) in HT cows compared with CL cows during the transition period. Across treatments, gene expression of PRLR long form, suppressor of cytokine signaling (SOCS)2, SOCS3, acetyl-CoA carboxylase $\alpha(A C A C A)$, and lipoprotein lipase $(L P L)$ at $-20 \mathrm{~d}$ relative to calving was less $(P \leq 0.05)$ than that in early lactation (2 and $20 \mathrm{~d}$ relative to calving), and gene expression of PRLR short form tended to be less $(P=0.09)$ during the dry period than during early lactation. However, expression of cyclin D1 (CCND1) and IGF1 mRNA at d -20 was greater (time effect: $P<0.01)$ compared with that in lactation. In PBMC (Table 2), relative to CL, HT cows had increased ( $P$ $\leq 0.05) I G F 1$ and TNF mRNA expression during the transition period and upregulated $(P<0.05) I L 8$ and downregulated $(P=0.01)$ expression of fatty acid synthase $(F A S N)$ mRNA at 2 d relative to calving.

Regardless of treatment, increased $P R L R$ gene expression in the mammary gland from the dry period into early lactation probably reflects increased epithelial cell secretory activity in lactation because of the important role of PRL in mammary cell metabolism (Akers et al., 1981). Following increased gene expression of PRLR, expression of SOCS2 and SOCS3 mRNA may be upregulated in early lactation to act as feedback inhibitors of PRL signaling (Krebs and Hilton, 2001). It is suggested that IGF-II and IGFBP-5 are downstream effectors in the PRL signaling of the mammary gland (Accorsi et al., 2002; Brisken et al., 2002); however, patterns of IGF2 and IGFBP 5 mRNA expression during the transition period in the current study did not follow that of PRLR. Relative to tightly controlled transgenic or knockout mouse mammary epithelial cell models (Brisken et al., 2002) or in vitro bovine mammary tissue explants (Accorsi et al., 2002), the gene expression data of IGF2 and IGFBP5 observed in the current study may reflect the complexity of the endocrine events occurring around parturition. The elevated rate of mammary epithelial cell proliferation in the dry period (Capuco et al., 1997) is reflected in the current study by the greater gene expression of $C C N D 1$, which is the key regulator of the G1/S transition during the cell cycle, and IGF1, which is the local modulator of mammary growth (Akers, 2006) during the dry period.

In contrast to our hypothesis, no treatment or treatment $\times$ time effects were observed among most of the genes examined in the mammary gland. Based on these data, it seems that the enhanced mammary growth by cooling HT dry cows (Tao et al., 2011) is not associated with PRL signaling at the level of the individual mammary epithelial cell, because no differences in mammary tissue mRNA expression of genes related to PRL signaling were observed between treatments. Yet we observed no differences for any of the genes examined, despite a larger functional capacity for secretion at the gland level. Heat stress is related to increased

Table 2. Gene expression of the mammary tissue and peripheral blood mononuclear cells (PBMC) in cows exposed to either heat stress (HT) or cooling (CL) during the dry period (at $\mathrm{d}-20,2$, and 20 relative to calving) ${ }^{1}$

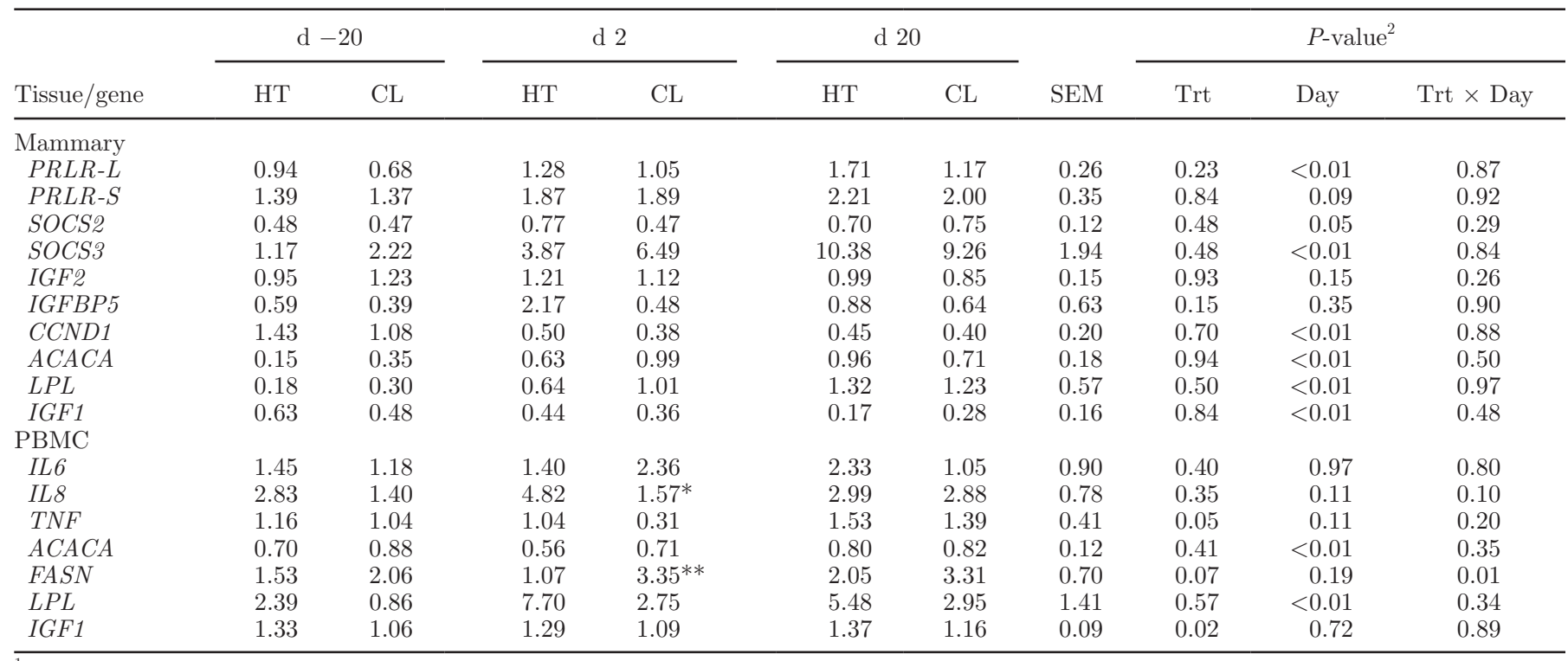

\footnotetext{
${ }^{1}$ The data were normalized to the most stably expressed reference genes and reported as the value relative to the geometric mean expression of the reference genes.

${ }^{2}$ Trt $=$ treatment; Trt $\times$ Day $=$ treatment by day interaction.

$* P<0.05,{ }^{* *} P=0.01$ within a day.
} 
blood PRL concentrations in dry cows (do Amaral et al., 2010; Tao et al., 2011), and the inverse relationship between circulating PRL and gene expression of PRLR in the mammary gland of cows exposed to different photoperiods (Dahl et al., 2012) led us to hypothesize that enhanced PRL signaling mediates upregulated mammary growth observed during the dry period in response to CL (Tao et al., 2011). Additionally, increased blood estrone sulfate and decreased progesterone concentrations in CL cows compared with HT cows (Collier et al., 1982) enhanced PRL signaling in the mammary gland (Tucker, 2000). Data in the current study indicate that the stressed condition by environmental heat may disrupt normal connections among the endocrine regulators in the mammary gland. Mammary cell apoptosis is influenced in part by IGFBP-5, and the addition of PRL negatively affects gene expression of IGFBP5 in bovine mammary tissue explants in vitro (Accorsi et al., 2002). Thus, the increase in PRL concentration (Tao et al., 2011) of HT cows is inconsistent with the expected mechanism for the slightly increased IGFBP5 gene expression observed in HT cows in the current study. Therefore, the mechanism of compromised mammary growth by HT during the dry period is still unknown and deserves further investigation. Additionally, similar gene expression of $A C A C A$ and $L P L$ between treatments indicates that both HT and CL cows may have similar secretory potential at the level of individual mammary epithelial cells but that CL cows have more secretory cells because of the enhanced mammary growth in the dry period and, thus, greater productive capacity compared with HT cows.

To our knowledge, this is the first study to report the effects of HT during the dry period on inflammatory cytokine gene expression in PBMC. Relative to CL cows, HT cows had increased TNF mRNA expression during the transition period. Tumor necrosis factor- $\alpha$ is a potent stimulator of $I L 8$ gene expression (Hoffmann et al., 2002). Therefore, following increased endogenous TNF- $\alpha$ production, IL 8 mRNA expression in HT cows was also upregulated in early lactation compared with CL cows. Under stressed conditions, cattle have an increased acute-phase response (Lomborg et al., 2008), which is mediated by enhanced inflammatory cytokine production (Petersen et al., 2004). Thus, the greater PBMC inflammatory cytokine mRNA expression of HT cows may reflect an adaptive response to environmental HT compared with CL cows. In human monocyte culture, addition of IGF-I results in enhanced TNF- $\alpha$ production and gene expression (Renier et al., 1996). Thus, the increased IGF1 mRNA expression in the PBMC of HT cows may enhance gene expression of inflammatory cytokines through a paracrine or autocrine pathway. In vitro responses to mitogen of PBMC isolated from HT cows included a reduced proliferation rate and reduced $\mathrm{TNF}-\alpha$ production during the transition period compared with CL cows (do Amaral et al., 2010). Combined with gene expression results, the impaired in vitro immune responses of HT cows probably indicate that, despite greater endogenous PBMC inflammatory cytokine mRNA expression, HT cows actually may have compromised immunological responses when encountering a pathogen compared with CL cows. The physiological explanation for increased FASN mRNA expression in CL cows relative to HT cows is unknown, but may be related to different immunological responses, as FA composition in immune cells dramatically influences their function (Calder, 2008).

In conclusion, cooling HT dry cows does not appear to affect the capacity of mammary cell FA synthesis during the transition period. The enhanced mammary growth observed through CL before parturition does not appear to be mediated by PRL signaling. Additionally, relative to CL cows, HT cows have increased PBMC inflammatory cytokine gene expression, which may be due to the effects of IGF-I.

\section{REFERENCES}

Accorsi, P. A., B. Pacioni, C. Pezzi, M. Forni, D. J. Flint, and E. Seren. 2002. Role of prolactin, growth hormone and insulin-like growth factor 1 in mammary gland involution in the dairy cow. J. Dairy Sci. 85:507-513.

Akers, R. M. 2006. Major advances associated with hormone and growth factor regulation of mammary growth and lactation in dairy cows. J. Dairy Sci. 89:1222-1234.

Akers, R. M., D. E. Bauman, A. V. Capuco, G. T. Goodman, and H. A. Tucker. 1981. Prolactin regulation of milk secretion and biochemical differentiation of mammary epithelial cells in periparturient cows. J. Endocrinology 109:23-30.

Auchtung, T. L., A. G. Rius, P. E. Kendall, T. B. McFadden, and G. E. Dahl. 2005. Effects of photoperiod during the dry period on prolactin, prolactin receptor, and milk production of dairy cows. J. Dairy Sci. 88:121-127.

Brisken, C., A. Ayyannan, C. Nguyen, A. Heineman, F. Reinhardt, J. Tian, S. K. Dey, G. P. Dotto, and R. A. Weingerg. 2002. IGF-2 is a mediator of prolactin-induced morphogenesis in the breast. Dev. Cell 3:877-887.

Calder, P. C. 2008. The relationship between the fatty acid composition of immune cells and their function. Prostaglandins Leukot. Essent. Fatty Acids 79:101-108.

Capuco, A. V., R. M. Akers, and J. J. Smith. 1997. Mammary growth in Holstein cows during the dry period: quantification of nucleic acids and histology. J. Dairy Sci. 80:477-487.

Collier, R. J., S. G. Doelger, H. H. Head, W. W. Thatcher, and C. J. Wilcox. 1982. Effects of heat stress during pregnancy on maternal hormone concentrations, calf birth weight and postpartum milk yield of Holstein cows. J. Anim. Sci. 54:309-319.

Connor, E. E., R. L. Baldwin, A. V. Capuco, C. M. Evock-Clover, S. E. Ellis, and K. S. Sciabica. 2010. Characterization of glucagonlike peptide 2 pathway member expression in bovine gastrointestinal tract. J. Dairy Sci. 93:5167-5178.

Dahl, G. E., S. Tao, and I. M. Thompson. 2012. Lactation Biology Symposium: Effects of photoperiod on mammary gland development and lactation. J. Anim. Sci. 90:755-760.

do Amaral, B. C., E. E. Connor, S. Tao, M. J. Hayen, J. W. Bubolz, and G. E. Dahl. 2010. Heat stress abatement during the dry pe- 
riod influences prolactin signaling in lymphocytes. Domest. Anim. Endocrinol. 38:38-45.

Hoffmann, E., O. Dittrich-Breiholz, H. Holtmann, and M. Kracht. 2002. Multiple control of interleukin-8 gene expression. J. Leukoc. Biol. 72:847-855.

Krebs, D. L., and D. J. Hilton. 2001. SOCS proteins: Negative regulators of cytokine signaling. Stem Cells 19:378-387.

Lomborg, S. R., L. R. Nielsen, P. M. H. Heegaard, and S. Jacobsen. 2008. Acute phase protein in cattle after exposure to complex stress. Vet. Res. Commun. 32:575-582.

Petersen, H. H., J. P. Nielsen, and P. M. H. Heegaard. 2004. Application of acute phase protein measurements in veterinary clinical chemistry. Vet. Res. 35:163-187.

Renier, G., I. Clement, A. Desfaits, and A. Lambert. 1996. Direct stimulatory effect of insulin-like growth factor-I on monocyte and macrophage tumor necrosis factor- $\alpha$ production. Endocrinology 137:4611-4618

Tao, S., J. W. Bubolz, B. C. do Amaral, I. M. Thompson, M. J. Hayen, S. E. Johnson, and G. E. Dahl. 2011. Effect of heat stress during the dry period on mammary gland development. J. Dairy Sci. 94:5976-5986.

Tucker, H. A. 2000. Hormones, mammary growth, and lactation: A 41-year perspective. J. Dairy Sci. 83:874-884.

Wall, E. H., T. L. Auchtung, G. E. Dahl, S. E. Ellis, and T. B. McFadden. 2005. Exposure to short day photoperiod during the dry period enhances mammary growth in dairy cows. J. Dairy Sci 88:1994-2003. 